\title{
Determination of Multiple Forms of Esterases in Rhizobium by Paper Electrophoresis
}

\author{
By P. M. MURPHY AND C. L. MASTERSON \\ Department of Soil Biology, The Agricultural Institute, \\ Johnstown Castle, Wexford, Irish Republic
}

(Accepted for publication 29 December 1969)

\begin{abstract}
SUMMARY
Fifty-two strains, comprising six Rhizobium species, were examined for their esterase patterns using electrophoresis on cellulose acetate. Esterase activity was detected in five Rhizobium species. The sixth species, $R$. japonicum, was characterized by the absence of esterase activity in all but one of the strains examined. Rhizobium trifolii and $R$. leguminosarum strains showed similarities in their esterase profiles. Rhizobium meliloti strains formed a group distinct from these on the basis of their esterase patterns. Rhizobium lotus $\mathrm{sp}$. and $R$. phaseoli also exhibited esterase activity.

Heat denaturation and metal inhibition studies suggest that the esterase activity is truly enzymic. The inability of the bacterial esterase to react with a synthetic peptide suggests that residual esterase activity associated with certain proteolytic enzymes is not involved. Heat tests revealed differences in the sensitivity of the multiple forms of esterases in rhizobia to inactivation.
\end{abstract}

\section{INTRODUCTION}

Studies on enzyme profiles in bacteria is a recent technique of considerable importance, which has been applied by a number of workers concerned with the classification of bacteria (Norris, I964; Lund, 1965; Cann \& Willox, 1965; Nakayama \& Takeya, 1967; Morichi, Sharpe \& Reiter, I968; Hogan \& Colwell, I969). The relatively high concentration of esterase activity in bacteria accompanied by the multiple nature and ease of detection of these enzymes has been responsible for their choice as markers in this process. In the present investigation, the intensity and electrophoretic nature of the esterase patterns of 52 strains from six Rhizobium species were determined to establish the relationship of these patterns to the present classification of these organisms. It was also intended to explore the possibility of using esterase patterns as identification markers for strains with similar nodulation and nitrogen fixation properties. Classically six Rhizobium species are recognized, comprising $R$. trifolii, $R$. leguminosarum, $R$. meliloti, $R$. phaseoli, $R$. japonicum and $R$. lupini (Bergey's Manual 1957). Currently, however, with the advent of improved techniques for studying cell components and the analysis of the resulting information by computers, certain changes in the original classification have been suggested (Lange, I96I; Graham, 1964; De Ley \& Rassel, I965; 't Mannetje, 1967; Moffett \& Colwell, 1968).

Although esterase activity in bacteria and fungi has been the subject of investigation by a number of workers (Norris, I964; Lund, I965; Cann \& Willox, I965; Robinson, I966; Moustafa \& Greenwood, I967; Nakayama \& Takeya, 1967; Peberdy \& Turner, 
I968; Hogan \& Colwell, I969) there is little information available on the nature of the activity, particularly with respect to rhizobia. Such information is desirable especially in view of the existence of non-enzymic esterase activity (Downey \& Andrews, 1965) and residual esterase activity associated with certain proteolytic enzymes (Kimmel \& Smith, 1954). This report contains results of preliminary investigations on the effects of mercurial and thermal treatments on the bacterial esterase with a view to establishing the nature of this activity in rhizobia.

\section{METHODS}

Origin and number of strains. Fifty-two Rhizobium strains, comprising several species were used in this investigation. The sources of the test strains and their nitrogen fixation performance are given in Table $\mathrm{I}$.

Culture of rhizobia. Test cultures were maintained on slopes of yeast-extractmannitol-agar (YEMA) at $4^{\circ}$ after $72 \mathrm{hr}$ growth at $25^{\circ}$ (Allen, 1957). A suspension of

\section{Table I. Characteristics and sources of Rhizobium strains}

\begin{tabular}{|c|c|c|c|c|c|}
\hline Species & Strain no. & Source* & Test host & N-Fixation $\dagger$ & Zymogram no. \\
\hline R. trifolii & $\begin{array}{l}\mathrm{J} 728 \\
\mathrm{~J} 752 \\
\text { CORYN } \\
\text { AF I } 2 \\
\mathrm{~J} 755 \\
\mathrm{~J} 735 \\
\mathrm{~J} 708 \\
\mathrm{~J} 731 \\
\mathrm{~J} 729 \\
\mathrm{~J} 733 \\
\mathrm{~J} 736 \\
\mathrm{~J} 738 \\
\mathrm{~J} 732 \\
\mathrm{~J} 730 \\
\mathrm{~J} 734 \\
\mathrm{~J} 737 \\
\mathrm{~J} 739 \\
\mathrm{~J} 740\end{array}$ & $\begin{array}{l}\text { J.C. } \\
\text { J.C. } \\
\text { R. } \\
\text { R. } \\
\text { J.C. } \\
\text { J.C. } \\
\text { J.C. } \\
\text { J.C. } \\
\text { J.C. } \\
\text { J.C. } \\
\text { J.C. } \\
\text { J.C. } \\
\text { J.C. } \\
\text { J.C. } \\
\text { J.C. } \\
\text { J.C. } \\
\text { J.C. } \\
\text { J.C. }\end{array}$ & Trifolium repens & $\left\{\begin{array}{l}+ \\
+ \\
- \\
- \\
+ \\
+ \\
+ \\
- \\
- \\
+ \\
+ \\
- \\
- \\
- \\
+ \\
- \\
- \\
-\end{array}\right.$ & $\begin{array}{r}1 \\
2 \\
3 \\
4 \\
5 \\
6 \\
7 \\
8 \\
9 \\
10 \\
11 \\
12 \\
13 \\
14 \\
15 \\
16 \\
17 \\
18\end{array}$ \\
\hline R. leguminosarum & $\begin{array}{l}1001 \\
1004 \\
1013 \\
1016 \\
1019 \\
1010\end{array}$ & $\begin{array}{l}\text { R. } \\
\text { R. } \\
\text { R. } \\
\text { R. } \\
\text { R. } \\
\text { R. }\end{array}$ & Vicia hirsuta & $\begin{array}{l}+ \\
- \\
+ \\
- \\
-\end{array}$ & $\begin{array}{l}19 \\
20 \\
21 \\
22 \\
23 \\
24\end{array}$ \\
\hline R. leguminosarum & $\begin{array}{l}1007 \\
307 \\
337 \\
341\end{array}$ & $\begin{array}{l}\text { R. } \\
\text { W. } \\
\text { W. } \\
\text { W. }\end{array}$ & $\begin{array}{c}\text { Pisum sativum } \\
\cdot \\
\cdot \\
\cdot\end{array}$ & $\begin{array}{l}+ \\
\text { n.d. } \\
\text { n.d. } \\
\text { n.d. }\end{array}$ & $\begin{array}{l}25 \\
26 \\
27 \\
28\end{array}$ \\
\hline R. meliloti & $\begin{array}{l}2009 \\
2010 \\
2011 \\
2012 \\
2013 \\
2006 \\
2007\end{array}$ & $\begin{array}{l}\text { R. } \\
\text { R. } \\
\text { R. } \\
\text { R. } \\
\text { R. } \\
\text { R. } \\
\text { R. }\end{array}$ & Medicago sativa & $\begin{array}{l}- \\
+ \\
+ \\
+ \\
+ \\
+ \\
+\end{array}$ & $\begin{array}{l}29 \\
30 \\
31 \\
32 \\
33 \\
34 \\
35\end{array}$ \\
\hline R. phaseoli & $\begin{array}{l}3601 \\
3603 \\
3604\end{array}$ & $\begin{array}{l}\text { R. } \\
\text { R. } \\
\text { R. }\end{array}$ & $\begin{array}{l}\text { Phaseolus vulgaris } \\
\text { Phaseolus vulgaris } \\
\text { Phaseolus vulgaris }\end{array}$ & $\begin{array}{l}+ \\
- \\
-\end{array}$ & $\begin{array}{l}36 \\
37 \\
38\end{array}$ \\
\hline
\end{tabular}


Table I cont.

\begin{tabular}{|c|c|c|c|c|c|}
\hline Species & Strain no. & Source* & Test host & N-Fixation $\dagger$ & Zymogram no. $\ddagger$ \\
\hline \multirow[t]{6}{*}{ R. japonicum } & $340 \mathrm{I}$ & R. & Glycine $\max$ & - & 39 \\
\hline & 3402 & R. & Glycine $\max$ & + & 40 \\
\hline & 3404 & R. & Desmodium uncinatum & - & $4 \mathrm{I}$ \\
\hline & 3405 & R. & Desmodium uncinatum & - & 42 \\
\hline & $5 \mathrm{II}$ & W. & . & n.d. & 43 \\
\hline & 5527 & W. & . & n.d. & 44 \\
\hline \multirow[t]{4}{*}{ R. lotus sp. } & A 166 & $\mathrm{H}$. & Lotus corniculatus & + & 45 \\
\hline & A I 68 & H. & Lotus corniculatus & + & 46 \\
\hline & $\mathrm{J} 202$ & J.C. & & n.d. & 47 \\
\hline & J 204 & J.C. & Lotus corniculatus & + & 48 \\
\hline \multirow[t]{4}{*}{ R. lotus sp. } & $\mathrm{J} 20 \mathrm{I}$ & J.C. & & n.d. & 49 \\
\hline & 3001 & R. & Lotus corniculatus & + & 50 \\
\hline & 3002 & R. & Lotus corniculatus & + & $5 \mathrm{I}$ \\
\hline & 3206 & R. & Lotus corniculatus & - & 52 \\
\hline
\end{tabular}

* J.C., Agricultural Institute, Johnstown Castle, Wexford, Irish Republic. R., Dr P. S. Nutman, Rothamsted Experimental Station, Harpenden, Herts., England. H., Dr D. A. van Schrevan, Directie Wieringermeer, Kampen, Holland. W., Professor O. N. Allen, University of Wisconsin, Madison, U.S.A.

$\dagger+$, Effective in nitrogen fixation; - , ineffective in nitrogen fixation; n.d., nitrogen fixation characteristic not determined.

$\ddagger$ Zymogram no. refers to esterase pattern number in Fig. I.

freshly grown rhizobia was incubated in I 1. quantities of yeast-extract-mannitol-broth on a Brunswick gyrotory shaker for $72 \mathrm{hr}$ at $25^{\circ}$, when required for electrophoresis.

Preparation of cell-free extracts. The rhizobia were harvested by centrifugation at 23,000 $\mathrm{g}$ for $30 \mathrm{~min}$. using an M.S.E. high speed centrifuge. They were washed twice with distilled water and I g. rhizobia suspended in $3 \mathrm{ml}$. $0.05 \mathrm{M}$-phosphate buffer, $\mathrm{pH} 7 \cdot 0$. Cell-free extracts were prepared by sonication of the cooled suspension for 2 min. at $4^{\circ}$ using an M.S.E. 60 watt sonic disintegrator. Sonicated extracts were centrifuged at $38,000 \mathrm{~g}$ at $4^{\circ}$ for $40 \mathrm{~min}$. to remove cell debris.

Electrophoresis. The cell-free extracts were analysed by paper electrophoresis (Preston, Briere \& Batsakis, 1965; Mager, Blatt \& Abelman, 1966; Murphy et al. 1969). Eight-inch square sheets of cellulose acetate (Gelman Instrument Co., Michigan, U.S.A.), which permitted 8 samples to be processed simultaneously, were used. Ten $\mu$ l. samples were applied and electrophoresis conducted at $15^{\circ}$ using a continuous phosphate buffer system $0.05 \mathrm{M}, \mathrm{pH} 7.0$. The initial current applied was $15 \mathrm{~mA}$ and duration of electrophoresis was $90 \mathrm{~min}$. Results presented are the mean of at least two determinations. With all species examined preliminary tests were made to determine the direction of migration of the esterase bands.

Qualitative detection of esterases. On completion of electrophoresis the cellulose acetate sheets were immersed in a solution of $\alpha$-naphthyl acetate and fast blue salt for 30 min. (Lawrence, Melnick \& Weimer, I960). It was found that subsequent treatment of the stained sheet with o. I N-NaOH accentuated the colour of the dye in the areas of enzymic activity, which greatly facilitated the detection of weak esterase bands in the zymogram.

Peptidase activity. The synthetic peptide $N$ - $\alpha$-benzoyl-DL-arginine-p-nitroanilide$\mathrm{HCl}$ (BAPNA) was substituted for $\alpha$-naphthyl acetate and the same procedure followed as described for esterase determination. 


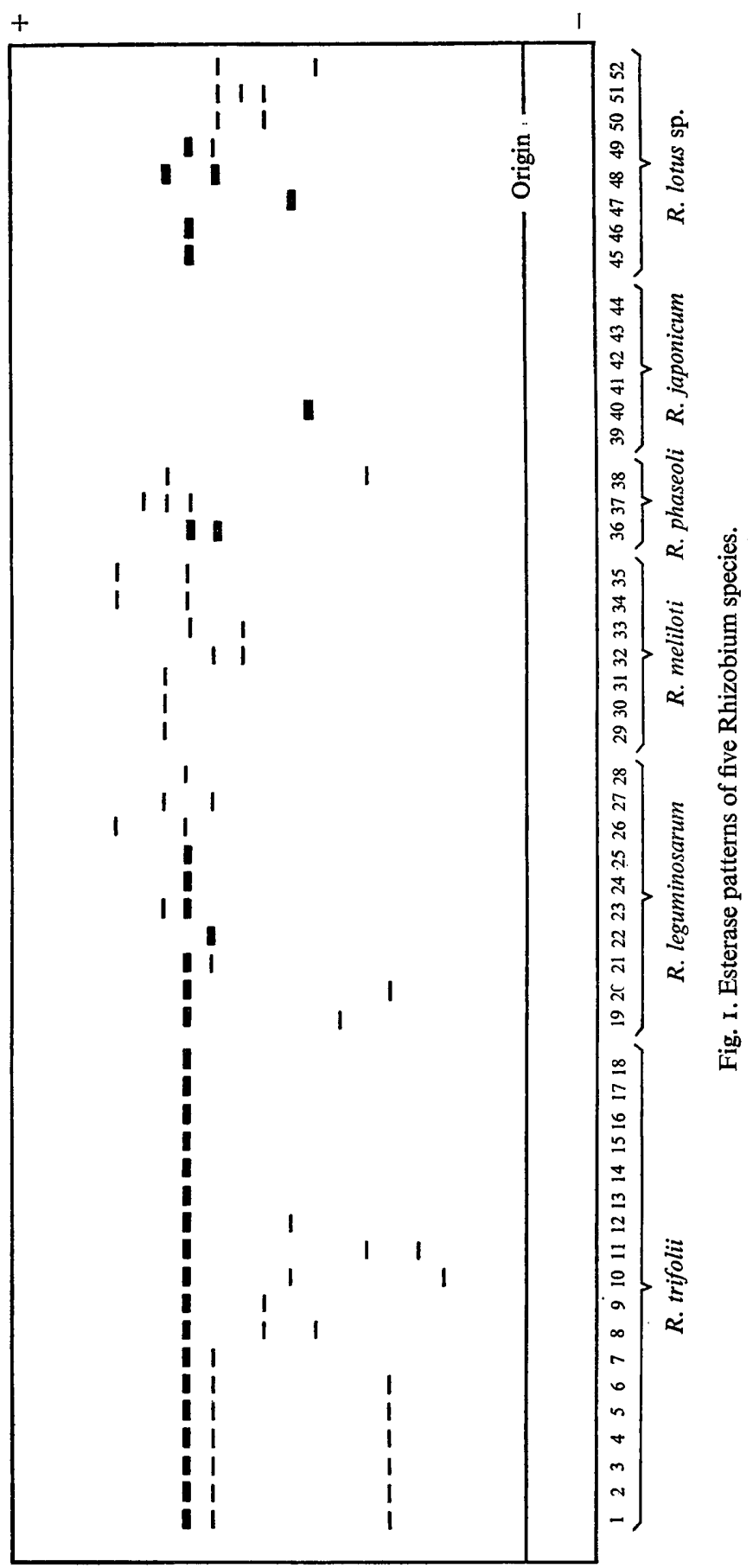


Quantitative determination of esterase activity. Esterase activity was determined spectrophotometrically at $410 \mathrm{~nm}$. in $0.05 \mathrm{M}$-phosphate buffer, $\mathrm{pH} 7.0$, at $15^{\circ}$ by measuring the formation of $p$-nitrophenol from $p$-nitrophenol acetate (Downey \& Andrews, 1965).

Protein determination. Protein concentrations were measured using the biuret reaction (Gornall, Bardawill \& David, 1949).

Heat inactivation of esterase activity. This was determined both quantitatively and qualitatively. For the former measurement enzyme solutions (I mg. protein/ml.) were heated at $45^{\circ}$ for various periods of time and esterase activity determined spectrophotometrically. For the latter measurement, enzyme solutions (Io mg. protein $/ \mathrm{ml}$.) were heated at various temperatures $\left(45^{\circ}\right.$ to $\left.75^{\circ}\right)$ for $10 \mathrm{~min}$. and the effect on the esterase electrophoretic pattern examined.

Effect of p-chloromercuribenzoate $(p C M B)$ on esterase activity. A stock solution of $p \mathrm{CMB}\left(\mathrm{I} \times \mathrm{IO}^{-3} \mathrm{M}\right)$ was prepared in $0.05 \mathrm{M}$ phosphate buffer, $\mathrm{pH} 7 \cdot 0$. Enzyme solutions (I mg. protein $/ \mathrm{ml}$.) were incubated with $p \mathrm{CMB}$ (final molarity $8 \times 10^{-4} \mathrm{M}$ ) for various periods of time and esterase activity determined spectrophotometrically.

\section{RESULTS}

Esterase patterns. The esterase patterns obtained from the Rhizobium cultures examined in this work are shown in Fig. I. Considerable esterase activity was found in all species with the exception of $R$. japonicum. In the latter species no activity could be detected in five strains, while the sixth strain tested showed one band of low mobility. Multiple esterase bands were obtained with most strains, the maximum number being three. In all instances, the direction of migration of the bands was from the cathode to the anode. It is evident from Fig. I that differences in esterase pattern exist not only between species but also between strains within species. In the case of $R$. trifolii (Fig. I, I to I8) these differences are evident only in the minor esterase bands as the major, fastest moving component, is common to all strains of this species. This component is quite prominent also in $R$. leguminosarum, occurring in six of the ten strains studied (Fig. I, I9 to 28). It is totally absent from strains of $R$. meliloti (Fig. I, 29 to 35 ) and $R$. japonicum (Fig. I, 39 to 44 ) and occurs in one of the $R$. phaseoli strains examined (Fig. I, 36 to 38 ) and in three of eight strains of $R$. lotus sp. (Fig. I, 45 to 52 ).

Peptidase activity. No peptidase activity was detected with any of the species using BAPNA as substrate.

Effect of heat on the esterase electrophoretic pattern. Figure 2 shows the effect of various temperature treatments, over a period of Io min., on the esterase electrophoretic patterns of four Rhizobium species. The esterases of the strain of $R$. trifolii studied were largely inactivated on heating to $45^{\circ}$ for $10 \mathrm{~min}$. The fastest moving component was totally inactivated and only a trace of the second component remained (Fig. 2). The R. lotus sp. strain, however, was resistant to inactivation at $45^{\circ}$. At $50^{\circ}$. the slowest moving component was inactivated but the fästest moving fraction was unaffected. This component was not inactivated until a temperature of $75^{\circ}$ was reached,

Similarly with the $R$. leguminosarum strain, the fastest moving component was unaffected at $45^{\circ}$ though the other two components were largely inactivated. No activity remained at a temperature of $75^{\circ}$. The esterase components of the $R$. meliloti strain were inactivated at $45^{\circ}$, only a trace of the fastest moving component remaining. 


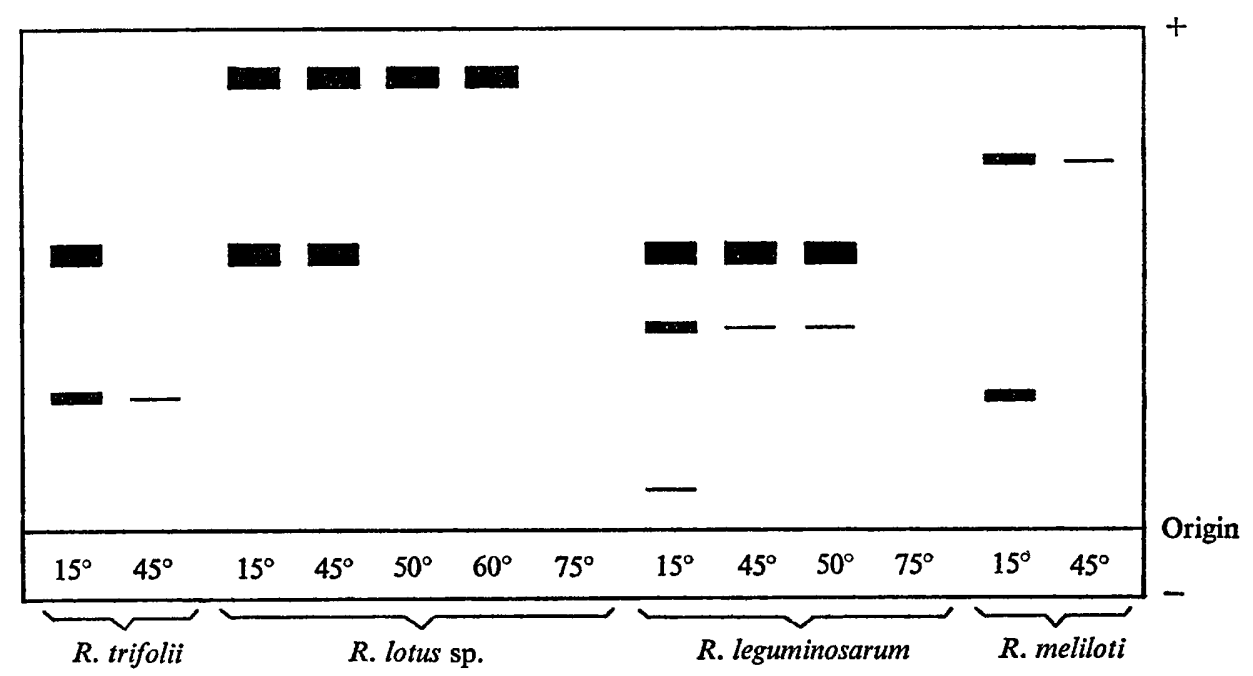

Fig. 2. Effect of heat on the electrophoretic esterase patterns of four Rhizobium species. Enzyme solutions ( $10 \mathrm{mg}$. protein $/ \mathrm{ml}$.) were heated at temperatures between $45^{\circ}$ and $75^{\circ}$ for Io min. and the electrophoretic esterase patterns then determined. The control sample ( $\left.15^{\circ}\right)$ was unheated.

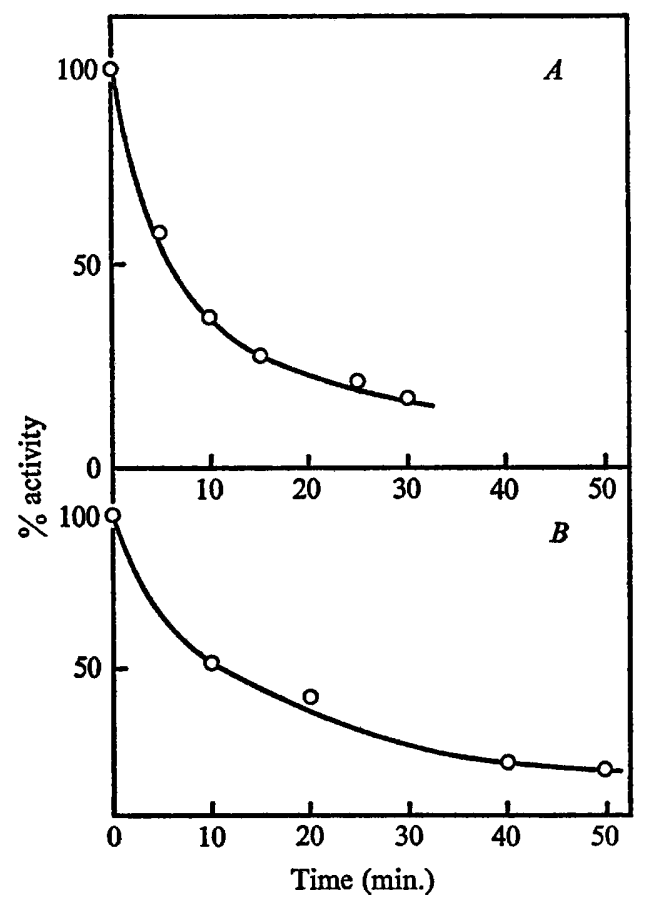

Fig. 3. (A). Heat inactivation of esterase activity. Cell-free extracts (I mg. protein/ml.) of a Rhizobium trifolii strain were heated at $45^{\circ}$ and esterase activity with time, determined spectrophotometrically at $4 \mathrm{IO} \mathrm{nm}$. $(B)$. Inhibition of esterase activity by $p$ CMB. Cell-free extracts (I mg. protein $/ \mathrm{ml}$.) were treated with $p \mathrm{CMB}\left(8 \times \mathrm{ro}^{-4} \mathrm{M}\right)$ and esterase activity determined with time. 
Figure $3 A$ shows the effect of heat on bacterial esterase activity of Rhizobium trifolii determined spectrophotometrically. The activity is very sensitive to heat being reduced by $50 \%$ in $7 \mathrm{~min}$. at $45^{\circ}$, a result which is in agreement with that depicted in the zymogram in Fig. 2. Figure $3 B$ shows the effect of $p$ CMB on esterase activity with time. Esterase activity is rapidly inactivated by this organomercurial reagent.

\section{DISCUSSION}

Results obtained in this work and illustrated in Fig. I reveal that in general the leguminous root nodule bacteria have high esterase activity. Fottrell (I968) demonstrated the presence of multiple esterase forms in the root nodule system, where up to ten bands of activity, comprising both anodic and cathodic fractions, were detected. The present report shows that fewer esterase components are present in the free-living bacteria and these are anodic in nature.

The zymogram patterns obtained from the strains tested reveal variation, especially between species, but also within species. Rhizobium trifolii and $R$. leguminosarum strains show the greatest similarity in esterase patterns and it is interesting to note that other workers have reported the occurrence of compatible characteristics in these two species (Graham, I964; Moffett \& Colwell, 1968; Fottrell \& O'Hora, 1969). Rhizobium meliloti strains appear to form a distinct grouping in agreement with the currently accepted classification of this species. The absence of esterase activity in most strains of $R$. japonicum is quite striking and in contrast to the presence of high activity in $R$. lotus sp. Moustafa \& Greenwood (1967) studied esterase and phosphatase activity in four strains of $R$. lotus sp. and found that the free-living rhizobia had similar enzyme patterns but differences in esterase profiles were encountered in the bacteroidal form.

The use of esterase patterns as a means for typing strains of rhizobia may have useful application. Patterns obtained are reproducible provided that experimental conditions are strictly adhered to. This is particularly true at the sonication step in the preparation of cell-free extracts, where excessive heat build-up may result in partial or total loss of enzyme activity.

There is no correlation between nitrogen-fixing abilities of the bacteria and their esterase patterns. This is illustrated in the case of Rhizobium trifolii (Fig. I, I to 6) where identical esterase patterns were obtained for strains showing different symbiotic responses (Table $\mathrm{I}$ ). These strains also represented isolates from mineral and peat soils.

Esterase activity has been associated with non-enzymic proteins (Downey \& Andrews, 1965) and some proteolytic enzymes also show esterase activity (Kimmel \& Smith, 1954). Conventional heat tests, which have demonstrated the susceptibility of the rhizobial esterase to denaturation coupled with the fact that no proteolytic activity was detected using BAPNA as substrate, suggest that 'true esterase' activity is involved. Esterases of $R$. trifolii and $R$. meliloti strains are very sensitive to heat denaturation being inactivated on heating at $45^{\circ}$ for ro min. Morichi et al. (1968) studied esterases of lactic acid bacteria and reported denaturation temperatures of $60^{\circ}$ and $65^{\circ}$ for Io min. Cann \& Willox (1965) reported on the presence of esterases in mycobacteria capable of withstanding $100^{\circ}$ for $10 \mathrm{~min}$. Esterases of $R$. lotus sp. bacteria were resistant to denaturation at $45^{\circ}$ and showed selective denaturation above this temperature. Rhizobium leguminosarum strains followed a similar pattern, a final temperature of $75^{\circ}$ 
being necessary to achieve complete denaturation of the esterase enzyme. Multiple forms of esterases in $\boldsymbol{R}$. lotus sp. and $R$. leguminosarum, therefore, differ not only in electric charge but also in sensitivity to heat denaturation. However, the comparative ease of denaturation of the esterase activity coupled with the absence of proteolytic activity suggests that the multiple forms are different expressions of a single enzyme activity. The sensitivity of the rhizobial esterases to heat denaturation, particularly $R$. trifolii and $R$. meliloti strains, emphasizes the need for carefully controlled temperature conditions when using sonication for cell disintegration. The present report has shown the sensitivity of the bacterial esterase to inhibition by $p$ CMB. Morichi et al. (1968) reported that the esterases in lactic acid bacteria were resistant to $10^{-4} \mathrm{M}-p \mathrm{CMB}$.

We wish to thank Messrs. S. Reynolds and A. Fanning for excellent technical assistance.

We also wish to thank Dr P.S. Nutman, Rothamsted Experimental Station, Harpenden, Herts., England; Dr D. A. van Schreven, Kampen, Holland, and Professor O. N. Allen, University of Wisconsin, U.S.A., for cultures of rhizobia.

\section{REFERENCES}

Allen, O. N. (1957). Experiments in Soil Bacteriology. Minneapolis 15: Burgess Publishing Co.

Bergey's Manual of Determinative Bacteriology (1957). 7th edition. Ed. by R. S. Breed, E. G. D. Murray \& N. R. Smith. Baltimore: Williams and Wilkins Co.

CANN, D. C. \& Willox, M. E. (1965). Analysis of multimolecular enzymes as an aid to the identification of certain rapidly growing mycobacteria, using starch-gel electrophoresis. Journal of Applied Bacteriology 28, 165 .

DE LEY, J. \& RASSEL, A. (1965). DNA-base composition, flagellation and taxonomy of the genus Rhizobium. Journal of General Microbiology 4r, 85.

DOWNEY, W. K. \& ANDREWs, P. (1965). Esterase activity of non-enzymic proteins of milk and serum. Biochemical Journal 96, 2 C.

FotTReLL, P. F. (1968). Esterase isoenzymes from legume root nodules. Phytochemistry 7, 23.

FotTrell, P. F. \& O'HORA, A. (1969). Multiple forms of D-3-hydroxybutyrate dehydrogenase in Rhizobium. Journal of General Microbiology 57, 287-292.

Gornall, A. G., Bardawill, C. J. \& David, M. M. (I949). Determination of serum proteins by means of the biuret reaction. Journal of Biological Chemistry 177, 75I.

GraHAM, P. H. (1964). The application of computer techniques to the taxonomy of the root-nodule bacteria of legumes. Journal of General Microbiology 35, $5 \mathrm{I}$ I.

HogaN, M. A. \& Colwell, R. R. (1969). DNA base composition and esterase patterns of bacteria isolated from deep sea sediments. Journal of Applied Bacteriology 32, I03.

Kimmel, J. R. \& Smith, E. L. (1954). Crystalline papain. I. Preparation, specificity and activation. Journal of Biological Chemistry 2, 515.

LANGE, R. T. (1961). Nodule bacteria associated with the indigenous Leguminosae of south-western Australia. Journal of General Microbiology 26, $35 \mathrm{I}$.

Lawrence, S. H., Melnick, P. J. \& Weimer, H. E. (1960). A comparison of serum proteins and enzymes by starch-gel electrophoresis. Proceedings of the Society for Experimental Biology and Medicine 105, 572.

LuND, B. M. (1965). A comparison by the use of gel electrophoresis of soluble protein components and esterase enzymes of some group D streptococci. Journal of General Microbiology 40, 413.

Mager, M., Blatt, W. F. \& Abelman, W. H. (1966). The use of cellulose acetate for the electrophoretic separation and quantitation of serum lactate dehydrogenase isoenzymes in normal and pathologic states. Clinica Chimica Acta $\mathbf{4} 4,689$.

'T MANNETJE, L. (1967). A re-examination of the taxonomy of the genus Rhizobium and related genera using numerical analysis. Antonie van Leeuwenhoek 33, 477. 
Moffett, M. L. \& Colwell, R. R. (1968). Adansonian analysis of the Rhizobiaceae. Journal of General Microbiology 5I, 245.

Morichi, T., Sharpe, M. E. \& Reiter, B. (1968). Esterases and other soluble proteins of some lactic acid bacteria. Journal of General Microbiology 53, 405.

MoustaFA, E. \& Greenwood, R. M. (1967). Esterase and phosphatase isoenzymes in rhizobia and rhizobial bacteroids in relation to strain effectiveness and proportion of nodule tissue in Lotus. New Zealand Journal of Science ro, 548.

Murphy, P. M., Noonan, M., Collins, P., Tully, E. \& Brady, T. G. (I969). Preparative isolation of the isoenzymes of adenosine deaminase. Biochimica et Biophysica Acta 17r, 157.

NAKAYAMA, Y. \& TAKEYA, K. (1967). Esterase zymogram method for classifying mycobacteria. Nature 213, 504 .

NoRRIS, J. R. (1964). The classification of Bacillus thuringiensis. Journal of Applied Bacteriology 27, 439.

Peberdy, J. F. \& TURNER, M. (1968). Esterases of Mortierella ramanniana in relation to taxonomy. Journal of General Microbiology 5I, 303.

Preston, J. A., Briere, R. O. \& Batsakis, J. G. (1965). Rapid electrophoretic separation of lactate dehydrogenase isoenzymes on cellulose acetate. American Journal of Clinical Pathology 43, 256.

Robinson, K. (I966). Some observations on the taxonomy of the genus Microbacterium. II. Cell wall analysis, gel electrophoresis and serology. Journal of Applied Bacteriology 29, 616. 